Chirurgia (2018) 113: 7-14

No. 1, January - February

Copyright@ Celsius

http://dx.doi.org/10.21614/chirurgia.113.1.7

\title{
Esophageal Surgery - Past, Present, Future
}

\section{Silviu Constantinoiu}

President of the Romanian Society of Surgery

General and Esophageal Surgery Department, Center of Excellence in Esophageal Surgery, Sf. Maria Clinical Hospital, Bucharest Carol Davila University of Medicine and Pharmacy, Bucharest, Romania

Corresponding author:

Professor Silviu Constantinoiu, MD, PHD Director of the Center for Excellence in Esofagian Surgery

General and Esophageal Surgery Department

Center of Excellence in Esophageal Surgery Sf. Maria Clinical Hospital, Bucharest

Carol Davila University of Medicine and

Pharmacy, Bucharest, Romania

E-mail: silviuconstantinoiu@gmail.com
At the drafting of the thematic number of „Chirurgia” journal, which is dedicated to esophageal surgery and pathology, I wanted to write an article which emphasizes the important role of Romanian surgery in this great field of European and worldwide surgery.

This is the reason why the number of articles written by experienced Romanian authors (both in the field of surgery and related specialties) is greater than those written by foreign authors.

From ancient times until now, the history of medicine has been connected to the evolution of human society, to the understanding of human anatomy and physiology and also to the technological progress in general. Of course the history of surgery (and of esophageal surgery in particular) couldn't be the exception (1).

Some authors divide medicine's evolution periods guiding themselves by milestone discoveries such as: asepsis and antisepsis methods, anesthesia, the discovery of antibiotics and chemotherapeutic drugs etc (2). Regarding the development of esophageal surgery, a decisive role was played by the introduction of general anesthesia with tracheal intubation and positive intermittent pressure and of selective bronchial intubation (1).

In the preface of "Esophageal Surgery and Pathology” published in 2017 at the Romanian Academy Publishing House, Professor Teodor Horvat proposes a Motto: „The esophagus passes through our country - the thorax"(1).

Even if it's an incontestable truth, the author notices that there are very few experienced thoracic surgeons specialized in 
esophageal surgery (and these are, in fact, general surgeons who have evolved towards thoracic surgery) (1).

A quote from R.G. EMSLIE (1988) brings light upon the seemingly insurmountable difficulties the pioneers of esophageal surgery have fought with: „the history of esophageal surgery is the story of people who are always defeated by stronger opponents, but who never stop fighting this war until, slowly, they win the fight (3). In fact, we cannot date a certain event which marks the birth of thoracic surgery and esophageal surgery in particular.

In 1862, EDWIN SMITH discovers, in Egypt, the papyrus which will be named after him, dated with approximation 2500 - 3000 B.C., which will be entirely translated and edited by HENRY BREASTED in 1930 (1). The content of this papyrus - case number 28- refers to a deep wound in the neck area involving the cervical esophagus which was apparently successfully treated. The first description of an esophageal cancer case can be found in a traditional Chinese text written more than 2000 years ago, in which the author describes a „swallowing problem" (dysphagia and regurgitation) in a certain patient. The famous Romanian doctor GALEN from PERGAM (131 - 200 A.D.) reported the signs of a fleshy mass obstructing the esophagus. The famous Arabian doctor AVICENNA (ABU IBN SINA), born in today's Tadjikistan, with a consulting and treatment cabinet in Bagdad, at the famous calif HAROUN - AL-RASHID's court, states in his famous Book of Medicine around 1025 that the most important symptom in esophageal tumors is dysphagia (3). J.L. COLLIS, in 1982, quotes from a comment of the famous campaign surgeon AMBROISE PARÉ (1510 -1590) (Fig. 1): „when the esophagus is sutured, a long period of patient's care awaits us". What a visionary he was! (4)

WILLIS (1674) treated dysphagia caused by achalasia with dilation of the lower esophagus with whale bones! For 2000 years the treatment of esophagus diseases was strictly symptomatic (5).

The first report regarding the placement of a gastrostomy tube for dysphagia caused by an esophageal tumor was in 1846 by WELSH and subsequent in 1849 by SEDILLOT (6).

The XIX-th century brings a great technological revolution, with the discovery of the incandescent bulb by THOMAS ALVA EDISON, thus allowing an appropriate light to the era's endoscopes (MAXIMILIAN NITZE, in Vienna, improves the cystoscope, then, the first rigid gastroscopes start to appear, and then, in 1868, ADOLF KÚSSSMAUL successfully passes a lighted tube along the esophagus as far as the stomach). (2) The starting point of esophageal resections belongs to THEODOR BILLROTH (Fig. 2) in Vienna in 1871, who practices experimental esophageal resections on dogs and cadavers, presenting aspects regarding the resection technique (3). Based on

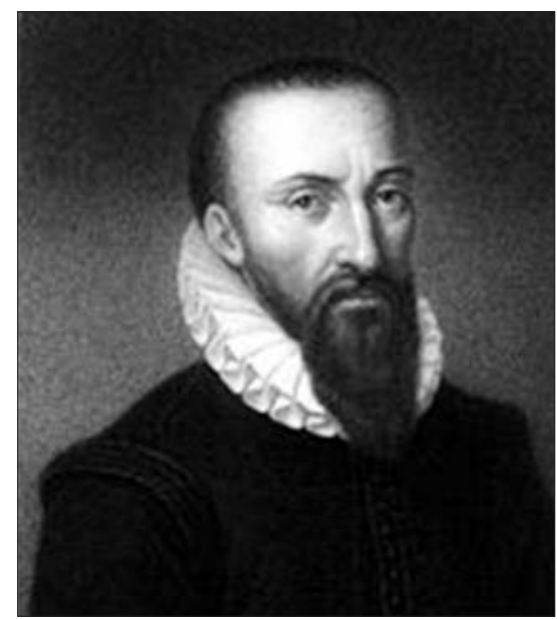

Figure 1. Ambroise Paré

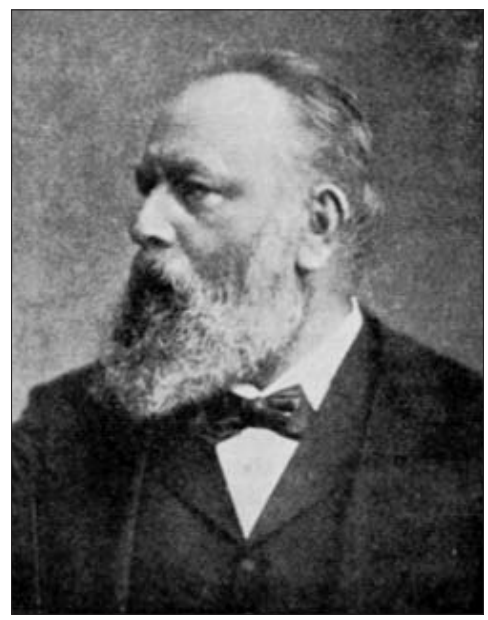

Figure 2. Theodor Billroth 
the studies of TH. BILROTH in 1877 in Heidelberg, VINCENT CZERNY (Bilroth's student) successfully performs the first cervical esophageal resection for esophageal cancer in human repairing the visceral defect with a cutaneous tube made from the skin of the region (3,6). JOHAN von MICULICZ RADECKI (named by OLCH, in 1960 the father of endoscopy as we know it today) together with JOSEPH LEITER from Vienna, make an endoscope with distal illumination (after the discovery of the incandescent bulb by Edison and the International Exposition of Electricity in Vienna in 1883) (2).

Von MICULICZ (from Breslau, Germany nowadays Wroclaw in Poland) who is FERDINAND SAUERBRUCH's teacher, considered the father of modern thoracic surgery, performs, as CZERNY, a cervical esophageal resection for esophageal cancer with cutaneous tube reconstruction $(3,6)$.

The main problem of thoracic esophageal resection was controlling the respiratory parameters during the thoracotomy. In 1904, the same von MICULICZ starts a differential pressure system to control respiration during the surgical intervention (7). His student, FERDINAND SAUERBRUCH was the main person in charge of building a negative differential pressure room made of a complicated system, where, both the patient and the team of doctors were locked in a sealed space, only the patient's head was outside the room for a better control of his respiratory function and the administration of the anesthetic agent. In fact, the most important concept, that of positive pressure ventilation via endotracheal tube (FELL-O' DWEYER-1893), wasn't exploited to it's full potential in respiratory support (6).

CHEVALIER JACKSON described the technique of direct laringoscopy and MELTZER and AUER described the technique of tracheal insuflation at the beginning of the XX-th century but only in 1930 GALE, WATERS and MAGILL introduce and popularize the direct view method (6). Along with the development of the selective lung intubation technique, surgeons will benefit from appropriate intraoperative conditions.

From now on we truly enter the modern era of esophageal surgery.

The biggest problems of contemporary esophageal surgery and pathology are represented by the growing incidence of Gastroesophageal reflux disease (GERD) - (and thus of Barrett's esophagus and esophagogastric junction adenocarcinoma) and of esophageal squamous cell carcinoma.

After FRANZ TÖREK (Fig. 3) successfully finishes in New York in 1913 the first thoracic esophagus resection (the patient has refused pretoracic cutaneous tube reconstruction and has been feeding for 13 years via a rubber tube which united the cutaneous esophagostomy with the gastrostomy), his success was soon forgotten (Fig. 4).

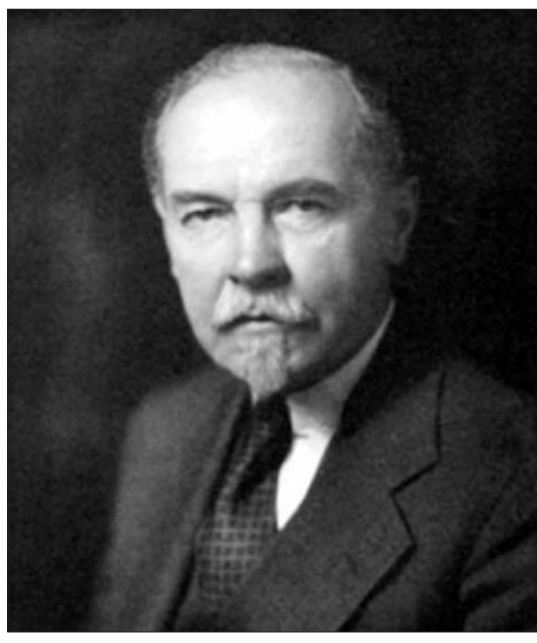

Figure 3. Franz Törek

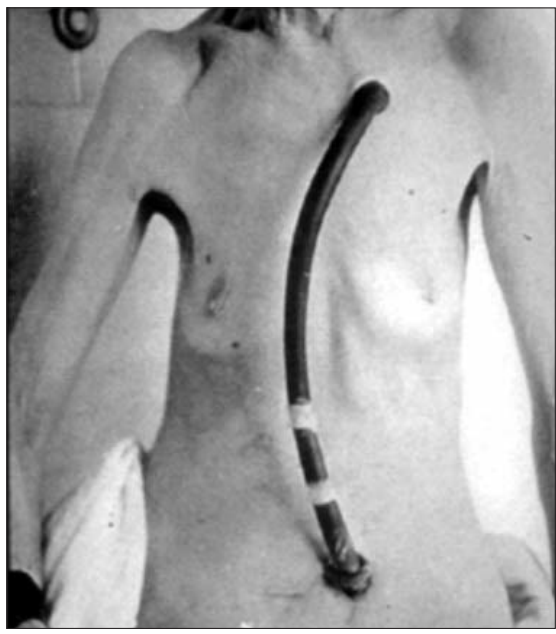

Figure 4. Pacienta doctorului Törek 
Subsequent FRANZ TÖREK's presentation at the American Medical Association in 1913 regarding the first successful subtotal esophagectomy, his paper was poorly received and didn't start any discussions. Although the first society (Society of Thoracic Surgery) was created in the USA in 1967, the concern for esophageal surgery was minor, DONALD PAULSON lamenting the poor experience of residents regarding this matter (only 6 to 9 cases operated annually reported by the American Board of Thoracic Surgery) (7).

Previously, in 1871, Th. Billroth successfully completed a cervical esophagus resection in a dog and then, in 1877, Czerny completed it in a human subject, and DOBROMYSSLOW in 1901 is the one who accomplished the first resection of $3-4 \mathrm{~cm}$ from the thoracic esophagus followed by an intrathoracic end-to-end anastomosis.

We have to remember the Romanian contribution of ION JIANU (Fig. 5), who, together with CLAUDE BECK from Cleveland - USA, brings forward almost simultaneously an anizoperistaltic tube made from the greater curvature for food to pass through (Beck -Jianu gastrostomy), which is then used to replace the distal esophagus and which was the foundation of the procedure of reconstructing the esophagus from the greater curvature with an anizoperistaltic tube proposed by AMZA JIANU (Fig. 6) and perfected by DAN GAVRILIU (Fig. 7).
Regarding AMZA JIANU's procedure, the esophageal neotube placed presternal didn't reach the cervical region and proposed, as a solution, a cutaneous graft interposition following BIRCHER technique which, not having the qualities of a digestive tube, was prone to multiple fistulas.

Prof. DAN GAVRILIU (Bucharest) improved the technique by adding a splenectomy ,in hilum"(the splenic artery becomes the feeding artery of the graft via the left gastroepiploic artery and the pancreatic body and tail are dissected until the right side of the abdominal aorta, so that the tube can easily reach presternal in the cervical region - the Gavriliu I procedure). Afterwards he brought the pylorus and DI to the neck (Gavriliu II), the graft reaches the pharynx and the digestive continuity is restored by a gastroduodenal anastomosis (9).

A very different type of esophagectomy is the one proposed by WOLFGANG DENK (1913, Vienna) who demonstrated on a corpse the blunt dissection of the esophagus via an abdominocervical approach without the necessity of a thoracotomy (7). GREY TURNER stated the first success via this method by performing an esophagectomy with a cervical esophagostomy and a gastrostomy as the first step, followed by an antethoracic cutaneous tube which connects the esophagostomy to the gastrostomy (7).

MARK ORRINGER (Fig. 8) and SLOAN refresh (in 1978, Ann Arbor) the transhiatal

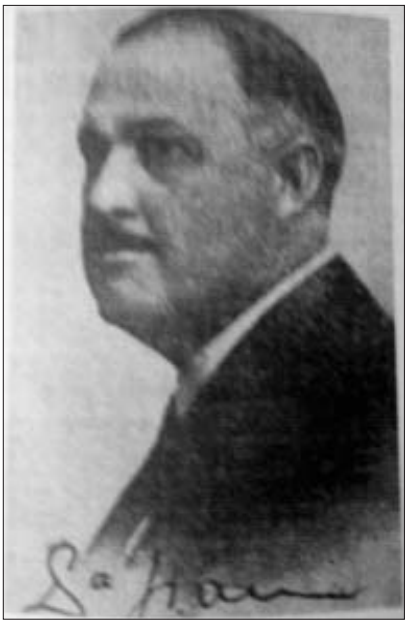

Figure 5. Ion Jianu

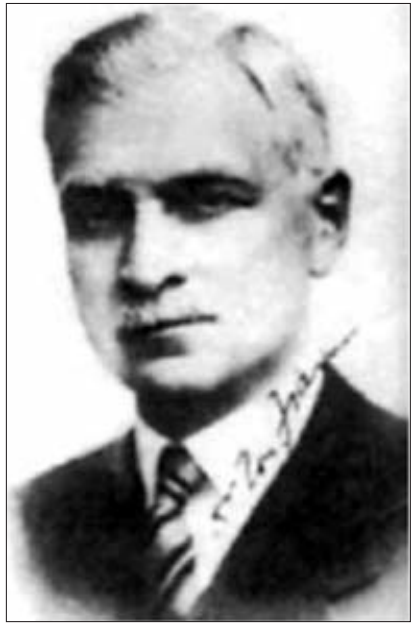

Figure 6. Amza Jianu

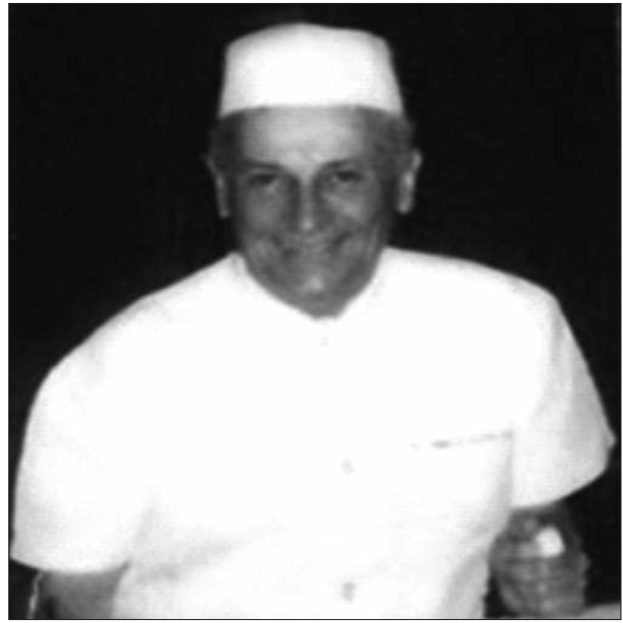

Figure 7. Dan Gavriliu 




Figure 8. Mark Orringer

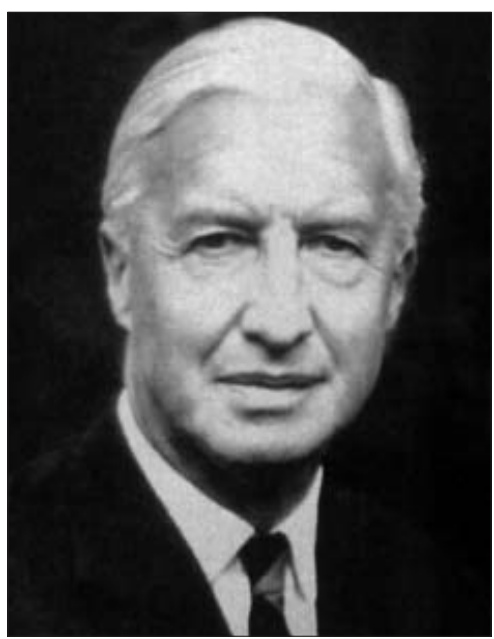

Figure 9. Phillip Allison

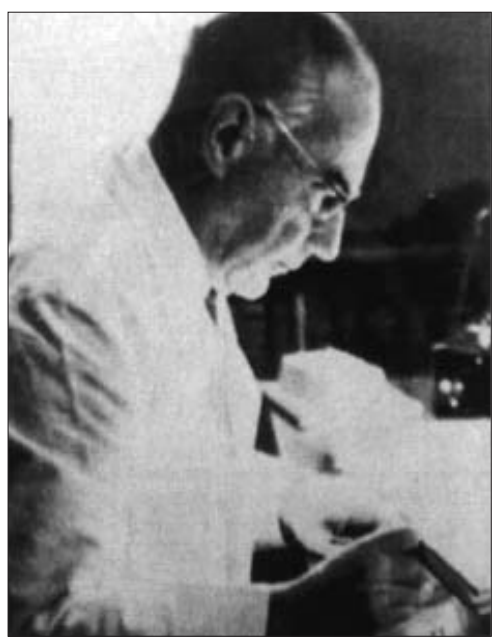

Figure 10. Rudolph Nissen abdomino-cervical dissection method foreseen by DENK and turned into reality by GREY TURNER by making possible the gastric pull-up and the cervical esophagogastric anastomosis $(8,10-12)$. The starting point of the authors is the idea that the survival rate is almost the same in advanced stages, but spares the patient of thoracotomy complications ( according to the American Association of Thoracic Surgery, the pleuro-pulmonary complications due to the dissection of the esophagus via thoracotomy - over 60\%!) and they have performed until now over 2000 such surgeries.

Regarding GERD, a turning point in it's evolution is represented by the discovery of the lower esophageal sphincter (SEI) (,high pressure zone" - HPZ) in 1956 by FYKE and CODE (2) based on manometric studies. Until this point, hiatal hernia with GERD surgery was strictly anatomical (ALLISON Fig. 9 $(18,19,25,26)$ via thorax and LORTAT -JACOB via abdomen) not addressing in any way the HPZ.

The surgeon who imagined the first complete 3600 valvuloplasty was RUDOLF NISSEN (Fig. 10) (1896 - 1981) born in Germany, the son of a prussian physician, he started his career in Munich in professor's F. SAUERBRUCH clinic by performing surgery on patients with pulmonary TBC, being the first surgeon to successfully perform a pneumonectomy in 1923, 2 years before EVARTS GRAHAM in the USA (17).

In 1933, due to Nazi persecution, he leaves Germany and becomes the head of the Department of Surgery in Istanbul, Turkey. Then he moves to New York and, in 1952, he returns to Europe, being until 1967 the head of the Department of Surgery of the University Hospital in Basel (Switzerland). In 1956 he improves the antireflux technique by proposing a 3600 gastric fundoplication around the esophagus having as a starting point one of his operations from 1936 ( a young woman aged 28 diagnosed with perforation of an esophageal ulcer into the pericardial cavity - after the transpleural resection of the distal esophagus, cardia and superior polar gastrectomy, he performed an esophagogastric anastomosis and, to prevent anastomotic fistula into the thorax, he performed the invagination of the anastomosis into the stomach and the plication of the gastric wall over the anastomosis similar to the gastrostomy, the WITZEL procedure, naming it continent esophagogastric anastomosis; postoperatively, Nissen noted the lack of reflux symptoms associated with this anastomosis).

However, until the 1950s, NISSEN uses ALLISON or HARRINGTON procedures for $\mathrm{H}$ $\mathrm{H}$ surgery with a high rate of recurrence; in 
1946 he imagines a gastropexy procedure which is named after him. In 1946, NISSEN was the head of the Department of Surgery of the Jewish Hospital from Brooklyn (Maimonides Hospital New York) and he operated on a famous radiologist from New York, dr. Gustav Bucky, who was diagnosed with a large paraesophageal hernia with gastric obstruction and hemorrhage. Although the best approach route at that time was thoracotomy, Nissen mobilizes and reduces the stomach via celiotomy, this approach being better tolerated by the patient. The stomach was sewn to the anterior parietal aponeurotic structures, thus establishing Nissen's gastropexy procedure (the patient's recovery was uneventful and without recurrence). Regardless of Nissen's procedure, the Dutchman BOEREMA publishes an anterior gastropexy procedure for a large hiatal hernia and NARBONA publishes a round ligament of the liver pexy of the esphagogastric junction procedure (17). At his return from Europe, Nissen re-examines the patient he operated on in 1936 for esophageal ulcer, noting the absence of reflux phenomena. Subsequent, being displeased by the results of the gastropexy procedure, he turns to WITZEL's idea, only this time he starts via laparotomy and leaves the esophagus intact. In 1955, in Basel, Nissen operates on a 49 years old female who had a 3 years history of esophagitis without $\mathrm{H} \mathrm{H}$. After the LaimerBertelli membrane is opened and the esophagus is dissected and pulled down into the abdomen, the gastric fundus is pulled and stitched in the posterior plane through a small opening in the lesser omentum and, without cutting the short vessels of the gastrosplenic epiploon, a sleeve surrounding the cardia and distal esophagus made from the anterior and posterior walls of the stomach is achieved - this procedure is called „gastroplication”; the dissection involved the last $6 \mathrm{~cm}$ of the distal esophagus and were needed 5 separated stitches, of which at least one passed trough the anterior esophageal wall to prevent gastric wrap telescoping.

Nissen publishes this case and another one (solved in the exact same way in a patient with H H and GERD) in 1956 (21). After 1970,
Nissen's procedure became the most used antireflux procedure - it was subsequent modified by other surgeons. His assistant, MARIO ROSSETTI, describes, in 1965, the use of only the anterior wall of the stomach to make the fundoplication. DONAHUE and associates have introduced the concept of „floppy Nissen”, by cutting the short vessels and reducing the height of the sleeve at $2 \mathrm{~cm}$ (to prevent postoperative early dysphagia or "gas bloat syndrome") (17).

For the same reasons, ALDAY and GOLDSMITH have modified Nissen's procedure, proposing a 2700 fundoplication. DOR proposes 1800 anterior partial fundoplication and ANDRÉ TOUPET posterior partial fundoplication $(1,2)$.

In 1950, NORMAN RUPERT BARRETT (Fig. 11), considered to be the dean of british surgeons, reports his experience regarding the metaplasia in the cells of the distal esophagus (the lining of the lower esophagus by simple columnar epithelium) - disease that will bear his name (french's endobrachyoesophage) (20, 22,23,27-32).

Among the promoters of laparoscopic antireflux surgery we must remember sir ALFRED CUSCHIERI (Fig. 12) from Dundee, Scotland, who, in 1989, accomplished a round ligament cardiopexy via laparoscopic approach reproducing the classic NARBONA ARNAU surgery. The first laparoscopic fundoplications were made by GEAGEA in Canada and BERNARD DALLEMAGNE in Belgium $(17,24)$.

Regarding colon esophageal reconstruction (we mention that the correct term is "reconstruction" and not esophagoplasty - means a limited stricture or stenosis which is solved by a local plasty or by suturing another digestive organ without replacing the whole esophagus) we mention firstly KELLING, who, in 1911, used left izoperistaltic colon for an esophageal cancer and also, VULLIET $(3,6)$ who proved the possibility of using anizoperistaltic right colon on corpses.

Right izoperistaltic colon was used for the first time by ROITH $(3,6)$ in 1924 and left and transverse colon by ORSONI and LEMAIRE (14-16). 


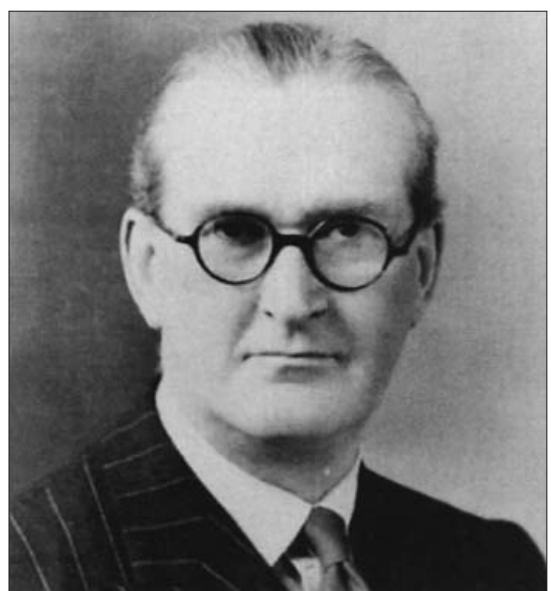

Figure 11. Norman Barrett

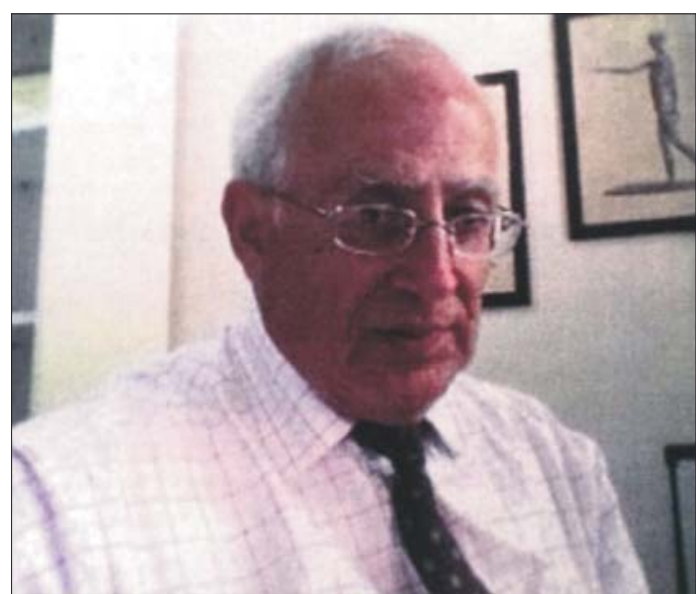

Figure 12. Sir Alfred Cushieri
In Romania, ZENO POPOVICI $(13,14)$ (recently departed from this world ) published interesting studies about colon vascularisation and also results after different reconstruction techniques, being OMS expert in pharyngoplasty procedures. Valuable results regarding colon esophageal reconstruction have also been recorded by EMILIAN PAPAHAGI (Floreasca Emergency Hospital), dr. KRISZAR (Oradea), Cluj, Timisoara and Iasi teams and the team of the Center of Excellence in Esophageal Surgery from Saint Mary Clinical Hospital Bucharest (who used, for the first time, a double vascular source for the vascularisation of the anizoperistaltic left and transverse colon graft: the middle colic artery and the superior left colic artery and used selective arteriography of Superior Mesenteric Artery and Inferior Mesenteric Artery in patients with caustic esophageal stenosis and who experienced failed esophageal reconstruction attempts in other units) (1).

With the laparoscopic and thoracoscopic approach, we enter the modern and contemporary era of esophageal surgery, soon followed by robotic surgery - already present in many surgical centers of excellence, which is set to become the gold standard of major esophageal surgery by minimizing the suffering of the patient, the time spent in the ICU and the total hospitalization time, faster social reinsertion; seriously buffering the high cost of technology and investment (but we will approach this topic in detail in the paper "minimally invasive esophagectomy for cancer" which can be found in this number of „Chirurgia” journal).

\section{References}

1. Constantinoiu S, Cordoș I, Ciuce C, Scripcariu V (eds). Tratat de patologie și chirurgie esofagiană. București: Editura Academiei Române; 2017.

2. Constantinoiu S. Istoricul chirurgiei mondiale și românești. În: Beuran M, editor. Curs de chirurgie pentru studenți, anul IV și V, vol. I. București: Editura Ilex; 2013. p. 1-21.

3. Bolca C. Probleme actuale în esofagoplastia cu colon - Teză de doctorat - Univ. „Lucian Blaga”, Sibiu, Fac. de Medicină „Victor Papilian”, 2012.

4. Hoară PA. Tulburările de motilitate esofagiană la pacienții cu esofag Barrett si implicatiile în managementu terapeutic - Teză de doctorat Univ. „Carol Davila”, București, 2015.

5. Constantin A. Actualităti în etiopatogenia si tratamentul diverticulilor esofagieni - Teză de doctorat - Univ. „Carol Davila”, București, 2012

6. Predescu DV. Coloesofagoplastia în stenozele esofagiene - Teză de doctorat - Editura Univ. „Carol Davila”, Bucuresti, 2011.

7. Wilkins EW Jr. The Historical Evolution of Esophageal Surgery în Esophageal Surgery, Second Edition, sub red. F. Griffith Pearson, J.D. Cooper, J. Deslauries, R.J. Ginsberg, C.A.Hiebert, G.A. Patterson, H.S. Urschell jr. New York, Edinburgh, London, Philadelphia: Ed. Churchill Livingstone; 2002. p 1-7.

8. Constantinoiu S. Subtotal abdomino-cervical esophagectomy (transhiatal, without thoracotomy, or Orringer's technique). Chirurgia (Bucur). 2005:100(5):479-87. Romanian

9. Gavriliu D. Chirurgia esofagului. București: Ed. Medicală; 1957.

10. Constantinoiu S. Patologia chirurgicală a esofagului. În: Angelescu N, Andronescu P, editors. Editura Medicală, Bucuresti, 2000, p. 283 - 347.

11. Constantinoiu S, Bîrlă R, losif C, Copcă N. Adenocarcinomul de jonctiune eso-gastrică. Bucuresti: Editura Medicală Amaltea; 2008.

12. Le Quesne LP, Ranger D. Pharyngolaryngectomy with immediate pharyngogastric anastomosis. Br J Surg. 1966;53(2):105-9.

13. Jezioro Z. - Formation of an artificial esophagus from the ileum. Pol Przegl Chir. 1958 Feb;30(2):111-8. Polish

14. Popovici Z. A new philosophy in esophageal reconstruction with colon. Thirty-years experience. Dis Esophagus. 2003:16(4):323-7. 
15. Orsoni P, Tooupet A. Use of the descending colon and the left part of the transverse colon for prethoracic esophagoplasty. Presse Med. 1950;58(44):804.

16. Orsoni $P$, Lemaire MJ. Esophagoplasty technique using the transverse and descending colon. J Chir (Paris). 1951;67(6-7):491-505.

17. Copăescu CA. Tratamentul laparoscopic al bolii de reflux gastroesofagian - Teză de doctorat, UMF „Carol Davila”, București, 2008.

18. Allison PR. Reflux esophagitis, sliding hiatal hernia, and the anatomy of repair. Surg Gynecol Obstet. 1951;92(4):419-31.

19. Allison PR. Hiatus hernia: (a 20-year retrospective survey). Ann Surg. 1973;178(3):273-6.

20. Barrett NR. Chronic peptic ulcer of the „oesophagitis”. Br J Surg. 1950;38:175.

21. Nissen R. Gastropexy and „fundoplication” in surgical treatment of hiatal hernia. Am J Dig Dis. 1961;6:954-61.

22. Constantinoiu S. Herniile hiatale. În: Angelescu N, editor. Tratat de Patologie Chirurgicală. Bucuresti: Ed. Medicală; 2001. p 1382-90.

23. Belsey R. Functional disease of the esophagus. J Thorac Cardiovasc Surg. 1966;52(2):164-88.

24. Dallemagne B, Weerts JM, Jehaes C, Markiewicz S, Lombard R. Laparoscopic Nissen fundoplication: preliminary report. Surg Laparosc Endosc. 1991;1(3):138-43.
25. Tileston W. Peptic ulcer of the oesophagus. Am J Med Sci. 1906; 132:240-65.

26. Allison PR, Johnstone AS. The oesophagus lined with gastric mucous membrane. Thorax. 1953;8(2):87-101.

27. Boscher LH, Taylor FH. Heterotopic gastric mucosa in the esophagus with ulceration and stricture formation. J Thorac Surg. 1951;21(3): 306-12.

28. Morson BC, Belcher JR. Adenocarcinoma of the esophagus and ectopic gastric mucosa. Br J Cancer. 1952;6(2):127-30.

29. Paull A, Trier JS, Dalton MD, Camp RC, Loeb P, Goyal RK. The histologic spectrum of Barrett's esophagus. N Engl J Med. 1976; 295(9):476-80.

30. Skinner DB, Walther BC, Riddell RH, Schmidt H. lascone C, DeMeester TR. Barrett's esophagus: comparison of benign and malignant cases.Ann Surg. 1983;198(4):554-65.

31. Spechler SJ, Zeroogian JM, Antonioli DA, Wang HH, Goyal RK. Prevalence of metaplasia at the gastro-oesophageal junction. Lancet. 1994;344(8936):1533-6.

32. Liu W, Hahn H, Odze RD, Goyal RK. Metaplastic esophageal columnar epithelium without goblet cells shows DNA content abnormalities similar to goblet cell- containing epithelium. Am J Gastroenterol. 2009;104(4):816-24. doi: 10.1038/ajg.2009.85. Epub 2009 Mar 17. 